\title{
CHARACTERIZATION AND REACTIVITY OF SILICA FUME
}

by

Alan D. Buck, J. P. Burkes

Structures Laboratory

U. S. Army Engineer Waterways Experiment Station

P. O. Box 631, Vicksburg, Miss. 39180

July 1981

Final Report

Approved For Public Release; Distribution Unlimited

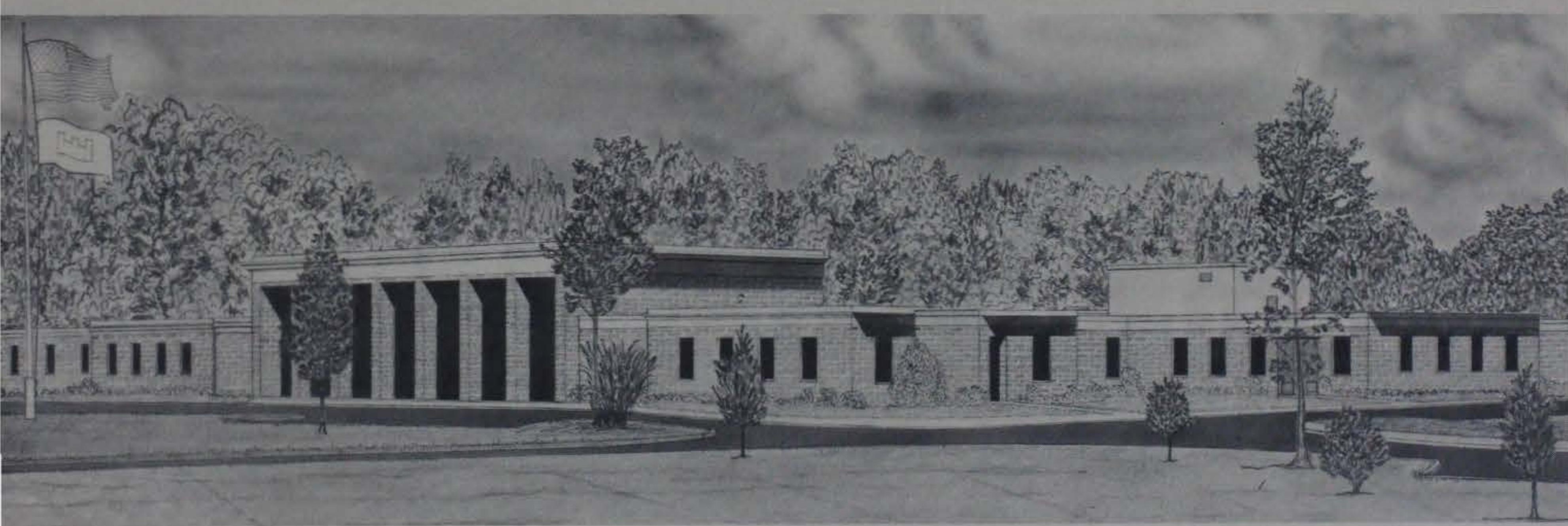

Prepared for Office, Chief of Engineers, U. S. Army

Washington, D. C. 20314

Under Civil Works Investigation Work Units

31294,31295 , and 31345

LIBRARY BRANCH

TECHNICAL INFORMATION CENTER

US ARMY ENGINEER WATERWAYS EXPERIMENT STATION VICKSBURG, MISSISSIPPI 


\begin{tabular}{|c|c|}
\hline REPORT DOCUMENTATION PAGE & $\begin{array}{c}\text { READ INSTRUCTIONS } \\
\text { BEFORE COMPLETING FORM }\end{array}$ \\
\hline \begin{tabular}{l|l} 
1. REPORT NUMBER & 2. GOVT ACCESSION NO. \\
Misce 11 aneous Paper SL- $81-13$ &
\end{tabular} & 3. RECIPIENT'S CATALOG NUMBER \\
\hline $\begin{array}{l}\text { 4. TITLE (and Subttite) } \\
\text { CHARACTERIZATION AND REACTIVITY OF SILICA FUME }\end{array}$ & $\begin{array}{l}\text { 5. TYPE OF REPORT \& PERIOD COVERED } \\
\text { Final report } \\
\end{array}$ \\
\hline $\begin{array}{l}\text { 7. AUTHOR(o) } \\
\text { Alan D. Buck } \\
\text { J. P. Burkes }\end{array}$ & $\begin{array}{l}\text { 6. PERFORMING ORG. REPORT NUMBER } \\
\text { 8. CONTRACT OR GRANT NUMBER(s) }\end{array}$ \\
\hline $\begin{array}{l}\text { 9. PERFORMING ORGANIZATION NAME AND ADDRESS } \\
\text { U. S. Army Engineer Waterways Experiment Station } \\
\text { Structures Laboratory } \\
\text { P. 0. Box } 631 \text {, Vicksburg, Miss. } 39180\end{array}$ & $\begin{array}{l}\text { 10. PROGRAM ELEMENT, PROOECT, TASK } \\
\text { AREA Q WORK UNIT NUMBERS TAS } \\
\text { CWI Work Units } \\
31294,31295 \text {, and } 31345\end{array}$ \\
\hline $\begin{array}{l}\text { 11. CONTROLLING OFFICE NAME AND ADDRESS } \\
\text { office, Chief of Engineers, U. S. Army }\end{array}$ & $\begin{array}{l}\text { 12. REPORT DATE } \\
\text { July } 1981\end{array}$ \\
\hline Washington, D. C. 20314 & $\begin{array}{l}\text { 13. NUMBER OF PAGES } \\
10\end{array}$ \\
\hline 14. MONITORING AGENCY NAME \& ADDRESS(II different from Controlling Offico) & $\begin{array}{l}\text { 15. SECURITY CLASS. (of thle roport) } \\
\text { UnClassified } \\
\text { 15a. DECLASSIFICATION/DOWNGRADING } \\
\text { SCHEDULE }\end{array}$ \\
\hline
\end{tabular}

16. DISTRIBUTION STATEMENT (OF this Roport)

Approved for public release; distribution unlimited.

17. DISTRIBUTION STATEMENT (of the abstract ontered in Block 20, if different from Report)

18. SUPPLEMENTARY NOTES

This is CTIAC Report No. 47. Report is available from National Technical Information Service, 5285 Port Royal Road, Springfield, Va. 22151.

19. KEY WORDS (Continue on reverse side If necessary and identify by block number)

Concrete technology

Laboratory tests

Pozzolans

Silica fume

20. ABSTAACT (Continue an roveree stios if necoersery and tdentify by block number)

Silica fume is a fine, siliceous powder that is a by-product of producing silicon metal or ferrosilicon in a reducing environment in an electric furnace. Recent research work on cementitious materials included characterization of such a silica fume from Alabama by chemical, physical, and petrographic tests. In addition, properties of mixtures of this fume with water and calcium hydroxide were studied. Compressive strengths were determined at different

(Continued) 
20. ABSTRACT (Continued).

ages, and the composition and microstructure of the hydrated material was studied by $X$-ray diffraction and by scanning electron microscopy.

The results show that the silica fume is characterized by small spheres of high silica content, by very high surface area, and is almost totally amorphous. Physical tests showed that it is a pozzolan, is effective in reducing expansion due to alkali-silica reaction, and increases the sulfate resistance of mortars. Combination of this material with water and calcium hydroxide results in the formation of extremely well crystallized Type I calcium silicate hydrate (CSH-I). 


\section{PREFACE}

The research that produced the results given in this paper was conducted for the Office, Chief of Engineers. It was part of Civil Works Investigation Work Unit 31294, "Minimize Alkali-Silica Reaction," Work Unit 31295, "Substitutes for Sulfate Resistant Cement," and Work Unit 31345, "Variations in Cementitious Media." The research was done in the Concrete Technology Division (CTD) of the Structures Laboratory (SL), U. S. Army Engineer Waterways Experiment Station (WES). Original approval for all of these investigations was provided in a Disposition Form dated 19 May 1975, Comment 1, Subject, "FY 76 and 76T Civil Works Research and Development Program," from Chief, Research and Development Office, DAEN-RDZ-A, to the Commander/Director of WES.

The work was done under the direction of Messrs. B. Mather, Chief, SL, and John M. Scanlon, Chief, CTD. Mrs. Katharine Mather was Project Leader for each of the projects. Mr. Alan D. Buck prepared this report from data provided by Mr. J. P. Burkes.

Funds for the publication of this report were provided from those made available for operation of the Concrete Technology Information Analysis Center (CTIAC). This is CTIAC Report No. 47.

LTC David C. Girardot, Jr., CE, was Acting Commander and $\mathrm{Mr}$. F. R. Brown was Acting Director of WES when this report was prepared. 


\section{CHARACTERIZATION AND REACTIVITY OF SILICA FUME*}

\section{INTRODUCTION}

Silica fume, also known as silica flour, amorphous silica, or volatilized silica, is a by-product waste material from the production of silicon or ferrosilicon metal.

Sixteen such fumes were examined at the Structures Laboratory of the U. S. Army Engineer Waterways Experiment Station (WES) as part of a Civil Works Investigation (CWI), Work Unit "Variations in Cementitious Media." One of these, from Alabama, was studied more extensively as part of two other CWI Work Units. These were "Substitutes for SulfateResistant Cements" and "Minimize Alkali-Silica Reaction."

Silica fume is a fine powder that is composed of tiny spheres of amorphous silica and fits the definition of a pozzolan in that it hardens when combined with calcium hydroxide (CH) and water (1). Considerable work in other countries has already called attention to this material as a solid waste problem and as a potentially useful material in cement and concrete (2-4).

\section{MATERIALS AND METHODS}

The silica fume was identified as AD-536(2). The CH was a commercial product. Distilled water was used.

Preliminary work included characterization of the fume by chemical analysis, physical tests, X-ray diffraction (XRD), and scanning electron microscopy (SEM).

The original mixtures were made using two parts of fume to one part $\mathrm{CH}$ by mass and enough water to achieve normal consistency by ASTM $C$ 187. Other mixtures were made with both two parts and one part of fume to one part of $\mathrm{CH}$ and more water.

Other mixtures at both fume to $\mathrm{CH}$ ratios were made to have a flow between 95 to 105 . One mixture was made to the same flow but with one part of fume to 2.25 parts of $\mathrm{CH}$. Cubes were molded from all mixtures, stored for $24 \mathrm{~h}$ at $23^{\circ} \mathrm{C}$ and thereafter at $38^{\circ} \mathrm{C}$ until being broken or examined by XRD and SEM. The initial series of tests were made at 7-, 28-, and 90-day ages. Some of the later mixtures were also tested at 56-, 180-, and 365-day ages.

Tests to evaluate the effectiveness of this fume in controlling

* Prepared for presentation at Third International Conference on Cement Microscopy in Houston, Texas, 16-19 March 1981. 
or reducing alkali-silica reaction and sulfate attack were made. The details will be reported elsewhere.

\section{RESULTS}

Tests of the fume (AD-536(2)) showed it to contain about 96 percent $\mathrm{SiO}_{2}$, a little over 1 percent $\mathrm{Al}_{2} \mathrm{O}_{3}$, and much smaller amounts of iron, magnesium, calcium, sulfur, sodium, and moisture. It was completely amorphous by XRD. SEM showed it to consist of small spheres.

The fineness of the fume was determined by the air-permeability method (ASTM Designation: C 204). However the material could not be used in the prescribed manner to produce a bed having a porosity of $0.530 \pm 0.005$. Hence the surface area was measured at three porosities, and by extrapolation to a porosity of 0.530 the surface area was judged to be $13 \mathrm{~m}^{2} / \mathrm{g}$. Silica fume from Norway and Sweden has been reported as having a surface area of about $20 \mathrm{~m}^{2} / \mathrm{g}(4)$. These fumes may be finer than the Alabama fume or the difference may lie in the extrapolation used. In any case, the Alabama fume was very much finer than most portland cements. Experience has indicated that handling of such fine powders may be the main problem standing in the way of their use as a pozzolan (4).

Data on four paste mixtures including water to solids ratios (W/S) from 0.69 to 1.06 and fume to $\mathrm{CH}$ ratios of 2 to 1,1 to 1 , and 1 to 2.25 are shown in Table 1 . These strengths ranged from $5.4 \mathrm{MPa}(770 \mathrm{psi})$ to $33.4 \mathrm{MPa}$ (4770 psi). In general, the strengths were about 20 to $33 \mathrm{MPa}$ when W/S was about 0.7 , about $10 \mathrm{MPa}$ when W/S was about 1.0 with one or two parts of fume, and about $7 \mathrm{MPa}$ when W/S was about 1.0 and the fume content was sharply reduced. There was no detectable effect on strength of the amount of fume when it was 1 or 2 parts of fume to 1 part $\mathrm{CH}$ and W/S was about 1.0 .

XRD showed that the amorphous fume had combined with the $\mathrm{CH}$ and water to form unusually well crystallized calcium silicate hydrate-I (CSH-I) by 7 days and the XRD patterns always showed this at all ages. Part of a typical XRD pattern is shown in Figure 1. CSH, unspecified as to Type I or II, is usually only detectable in XRD patterns of hydrated portland cement paste if at all as a vague hump. The partial XRD pattern shown in Figure 1 shows most of the peaks listed by Taylor (5) as CSH-I. Hara and Inone (6) report the formation of jennite from fumed silica but their work was carried out at $80^{\circ} \mathrm{C}$ while our work took place at $38^{\circ} \mathrm{C}$. Jennite is more crystalline than CSH. Study of XRD patterns of the different mixtures showed the following:

a. XRD peaks for $\mathrm{CH}$ were no longer found in samples of any of the mixtures containing two parts of fume after 7 days storage. Such peaks 
were present at 7 days in one of the mixtures containing one part of fume but were gone by 28 days.

b. A mixture containing one part of fume showed the best development of a 1.3-nm ( $13 \stackrel{0}{\AA}$ ) peak by XRD. In most XRD patterns there was only a slight indication of a spacing in that area.

c. CSH-I was the type of CSH found in all of the XRD patterns. The mixture containing 1.7 parts $\mathrm{CaO}$ to $\mathrm{SiO}_{2}$ ( $\mathrm{Table} 1$ ) was made to encourage the formation of $\mathrm{CSH}-\mathrm{II}$ since this compound requires more $\mathrm{CaO}$ than CSH-I (5), but no CSH-II formed. This mixture contained excess CH as it was present in large amounts in XRD patterns to one year.

d. There did not seem to be any significant change in the amount or crystallinity of the CSH-I with time or mixture proportions. It was always present with the XRD patterns by the 7-day testing age.

Scanning electron micrographs of all mixtures at all test ages showed generally consistent features regardless of mixture proportions or age. While most of the fume seemed to have been used up in the chemical reaction, an occasional residual sphere of the furne was seen at an age of one year. Figures 2, 3, and 4 show typical microstructures at different magnifications of a 7-day-old mixture made with one part fume, one part $\mathrm{CH}$, and $\mathrm{W} / \mathrm{S}$ of about 1.2. Since the starting materials were generally all used up in the hydration of the fume and XRD patterns showed only CSH-I, it was assumed that the material seen in these micrographs, if not obviously residual fume or $\mathrm{CH}$, was CSH-I. Figure 4 is a particularly good example of this CSH-I morphology. This structure seems to be crumpled foils as mentioned by Taylor (5, Plate 27 and pg. 372 ) for CSH-I. It also resembles the reticulated network described and illustrated by Diamond $(7,8)$ for CSH in cement paste.

K. Mather $(9,10)$ has reported on work at WES showing that this fume (AD-536(2)) is very effective in reducing expansion due to sulfate attack. Other work at WES has shown it is equally as effective in reducing expansion due to alkali-silica reaction.

\section{CONCLUSIONS}

This silica fume was composed of small amorphous spheres and had an $\mathrm{SiO}_{2}$ content of about 96 percent.

It was an effective pozzolan which shows promise for controlling or reducing alkali-silica reaction and sulfate attack in concrete.

Combination of this fume in different amounts with $\mathrm{CH}$ and water led to the formation of CSH-I by 7 days.

This CSH-I was much more crystalline than the CSH found in cement paste hydrated at normal temperatures. 


\section{REFERENCES}

1. American Society for Testing and Materials, "Standard Specification for Fly Ash and Raw or Calcined Natural Pozzolan for Use as a Mineral Admixture in Portland Cement Concrete" (ASTM Designation: C 618-80), Part 14, 1980 Annual Book of ASTM Standards, Philadelphia.

2. Asgeirsson, H., and Gudmundsson, G., "Pozzolanic Activity of Silica Dust," Cement and Concrete Research, Vol. 9, pp. 249-252, 1979, New York.

3. Traetteberg, A., "Silica Fumes as a Pozzolanic Material," Il Cemento, Vol. 75, No. 3, pp. 369-375, 1978, Rome.

4. Gutt, W., and Nixon, P. J., "Use of Waste Materials in the Construction Industry," Materials and Structures, Vol. 12, No. 70, pp. 289-290, 1979, Paris.

5. Taylor, H. F. W., The Cemistry of Cements, Vol. 2, pg. 327, 1964, Academic Press, N.Y.

6. Hara, N., and Inone, N., "Formation of Jennite from Fumed Silica," Cement and Concrete Research, Vol. 10, pp. 677-682, 1980, N.Y.

7. Diamond, S., "Application of SEM to the Study of Hydrated Cement," in Proc. of 3rd Annual SEM Symposium, pp. 385-32, 28-30 April, 1970, Illinois Institute of Technology, Chicago.

8. Diamond, S., "Structure of Cement Paste," in Hydraulic Cement Pastes: Their Structure and Properties, Proc. of a Conference held at the University of Sheffield, 8-9 April 1976, pp. 2-30, Cement and Concrete Assoc., Wexham Springs, Great Britain.

9. Mather, K., "Current Research in Sulfate Resistance at the Waterways Experiment Station," presented at the Verbeck Memorial Symposium, sponsored by ACI Committee 201 on Durability, 5 March 1980 , Las Vegas, Nev., in press.

10. Mather, K., "Factors Affecting Sulfate Resistance of Mortars," U. S. Army Engineer Waterways Experiment Station, Miscellaneous Paper SL-80-17, October 1980, Vicksburg, Miss., also in press for Proc. 7 th International Cong. on Chem. of Cement, Paris. 
TABLE 1

Physical Data for Pastes Made Using Silica Fume and Calcium Hydroxide

\begin{tabular}{|c|c|c|c|c|c|c|c|c|c|}
\hline $\begin{array}{l}\text { Lime } \\
\text { to } \\
\text { Silica }\end{array}$ & $\begin{array}{l}\text { Proportions of } \\
\text { Fume to Calcium }\end{array}$ & & $\begin{array}{l}\text { Water } \\
\text { to } \\
\text { Solids }\end{array}$ & & $\begin{array}{l}\text { ressi } \\
\text { Pays) } \\
\end{array}$ & $\begin{array}{l}\text { Str } \\
\text { Shown }\end{array}$ & $\begin{array}{l}\text { igth } \\
\text { Below }\end{array}$ & $\begin{array}{l}t \text { Ages } \\
\mathrm{MPa}^{*}\end{array}$ & \\
\hline Ratio & Hydroxide & Flow & Ratio & 7 & 28 & 56 & 90 & $\underline{180}$ & 365 \\
\hline$\sim 0.4$ & $2: 1$ & -- & 0.69 & 20.1 & 31.1 & -- & 33.4 & -- & -- \\
\hline 20.4 & $2: 1$ & 93 & 1.06 & 8.8 & 11.5 & 11.6 & 11.3 & 12.7 & 11.3 \\
\hline 0.8 & $1: 1$ & 95 & 0.98 & 9.3 & 11.8 & 10.8 & 11.6 & 10.9 & 11.9 \\
\hline น1.7 & $1: 2.25$ & 101 & 0.93 & 5.5 & 7.1 & 7.6 & 6.9 & 7.1 & 5.4 \\
\hline
\end{tabular}

* psi $\times 0.006894757=\mathrm{MPa}$ 


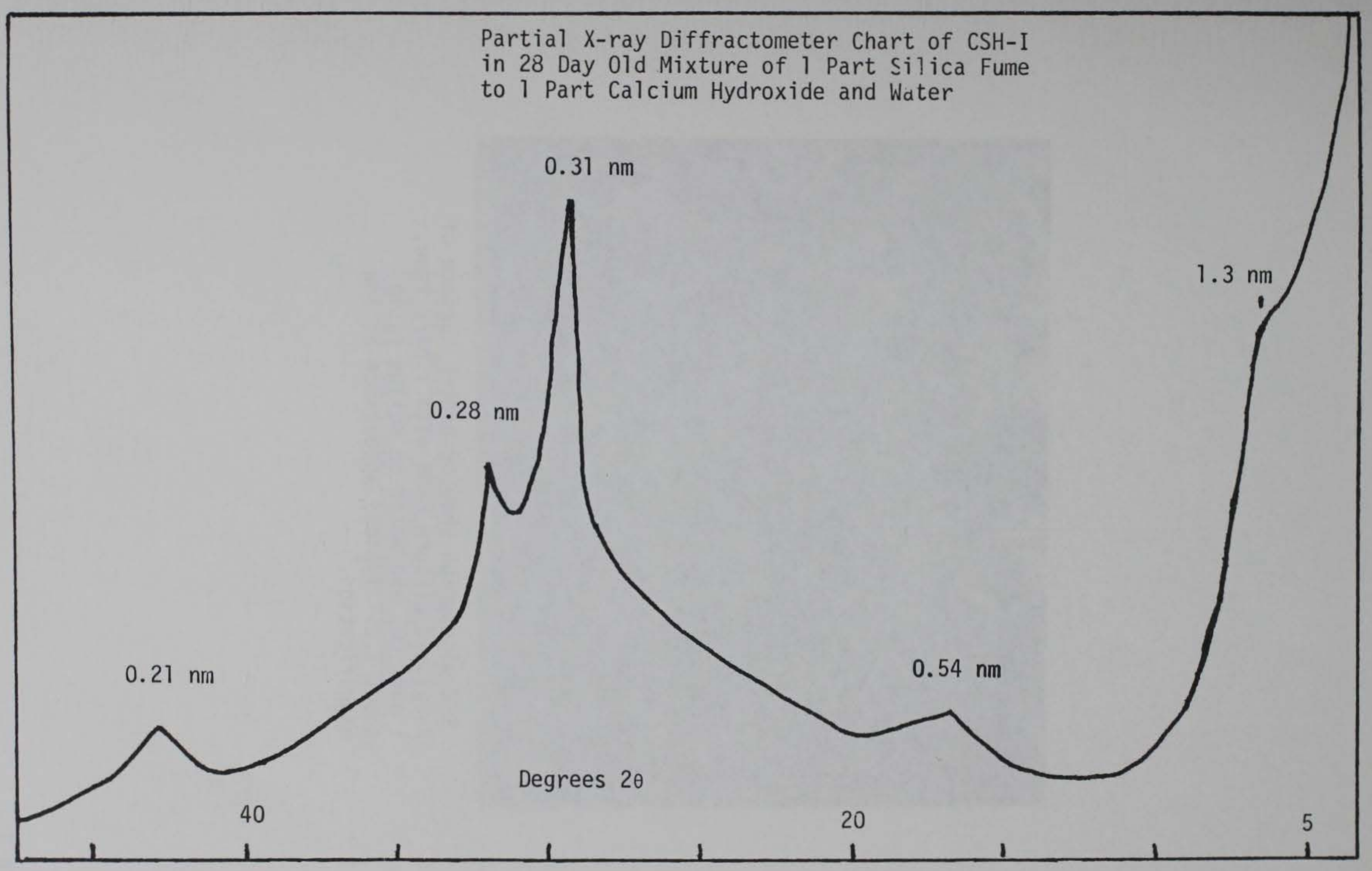

Figure 1 


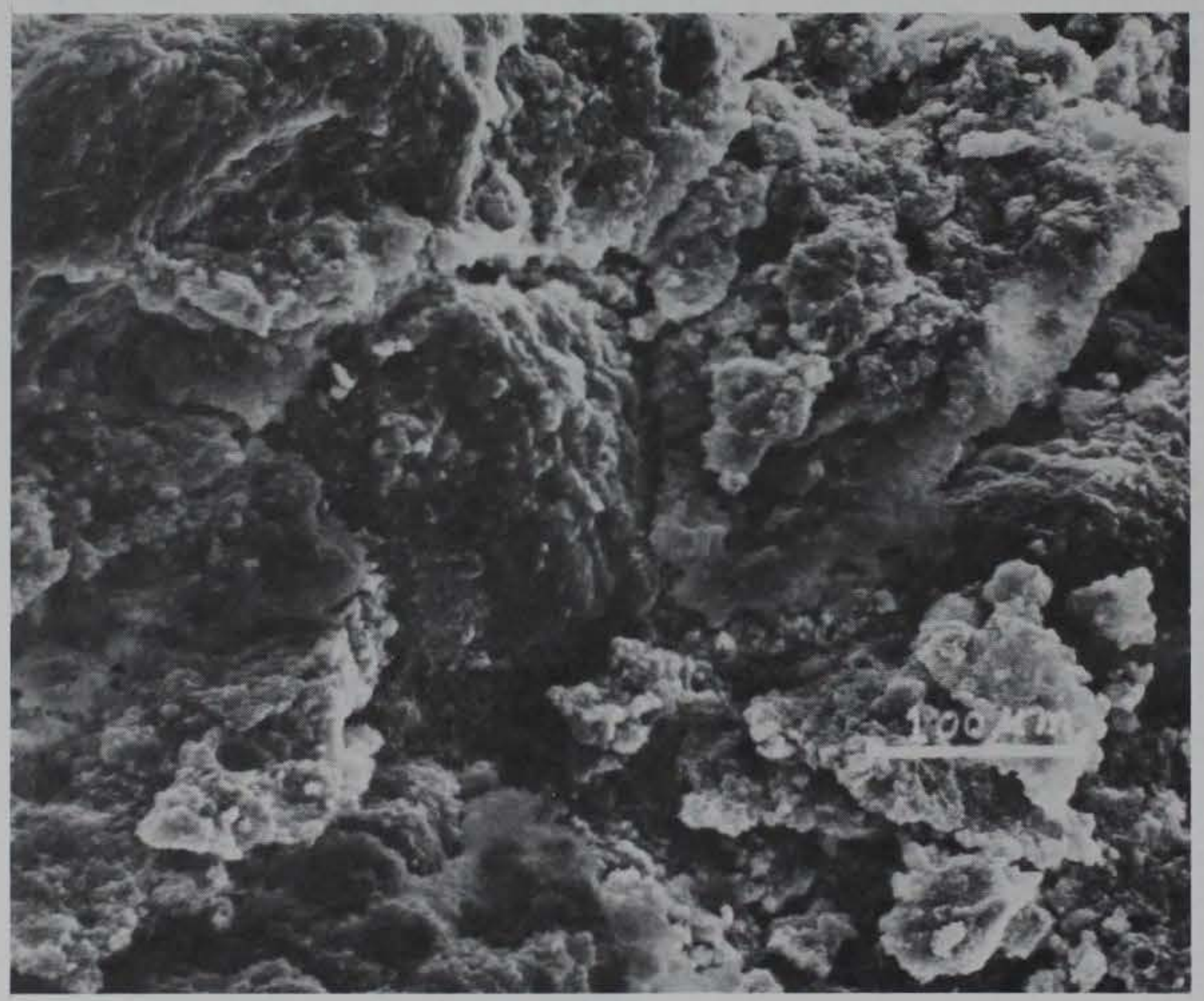

SEll micrograph showing broken surface of 7-day old mixture made with 1 part fume, 1 pari $\mathrm{CH}$, and water to solids ratio about 1.2. Typical appearance at low magnification. 


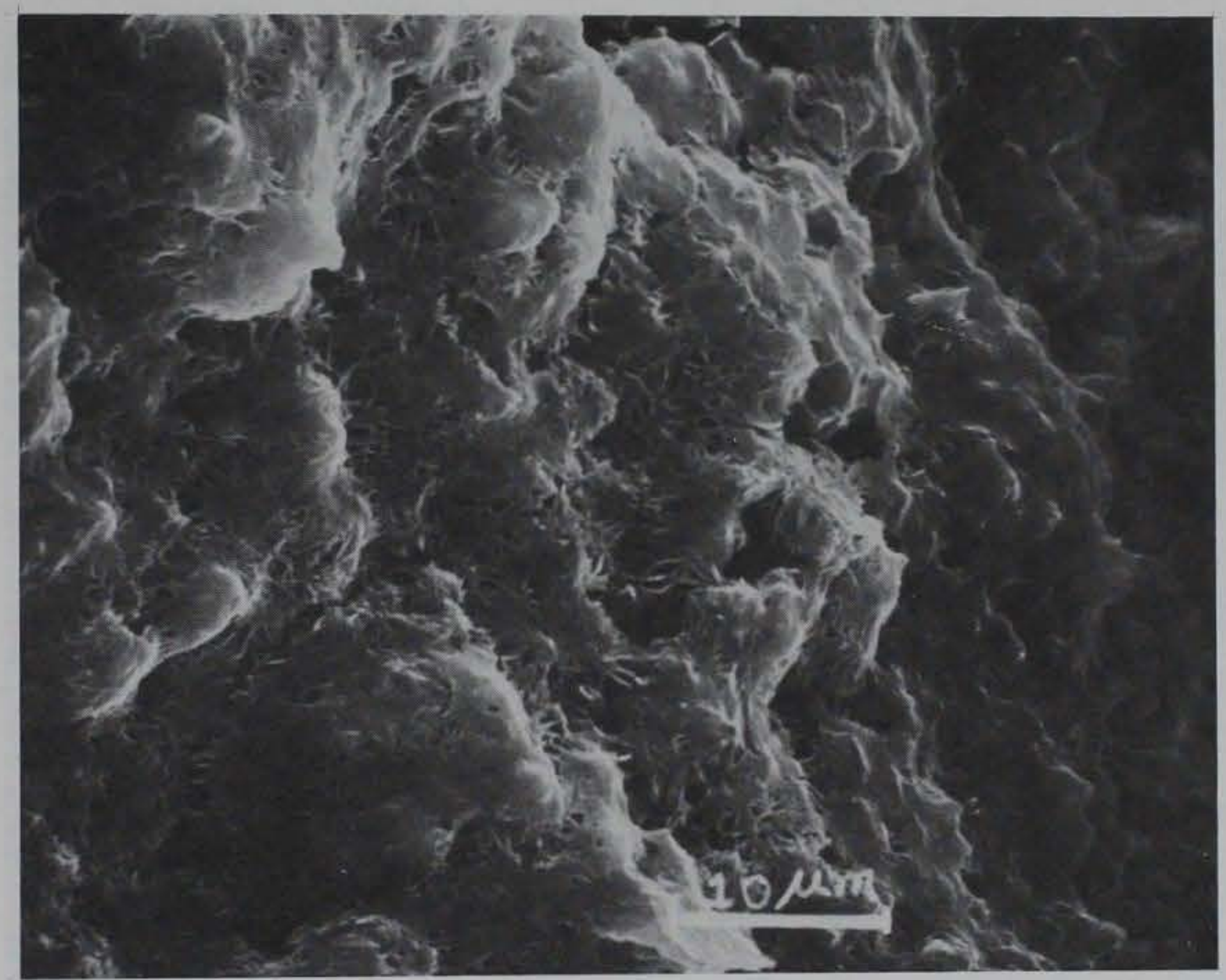

Enlargement of central portion of

Figure 2. Void space and details of the CSH-I are becoming evident. 


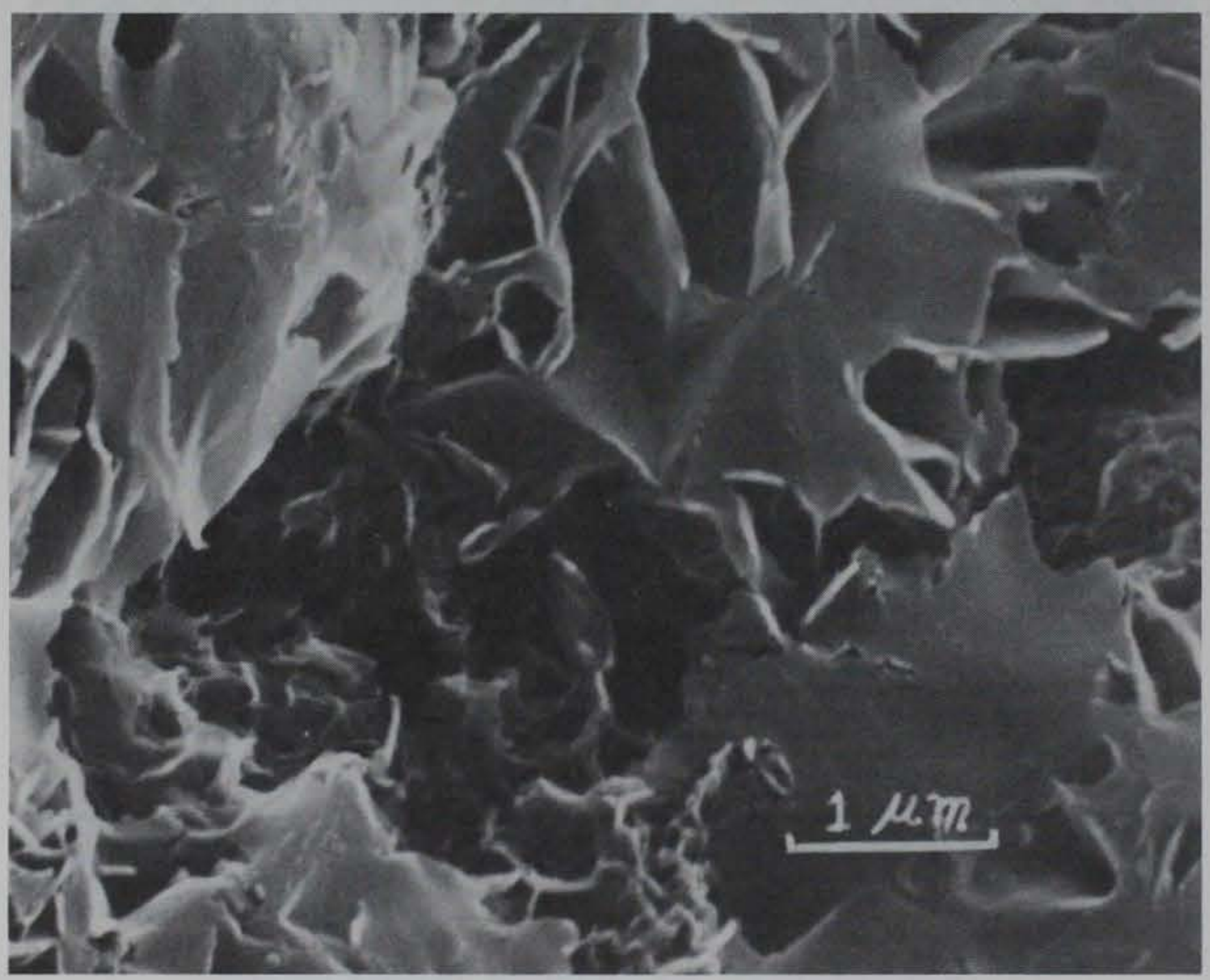

Enlargement of central portion of Figure 3. The size and shape of the CSH-I crystals are apparent.

Figure 4 